P-ISSN: 1978-7227 E-ISSN: 2615-3017

doi : https://doi.org/10.30598/barekengvol14iss2pp279-292

National Accredited in SINTA 3, Decree No.: 28/E/KPT/2019

\title{
PENERAPAN METODE UNIVERSAL KRIGING (UK) UNTUK PREDIKSI KONSENTRASI PARTICULATE MATTER 2.5 (PM 2.5$)$ DI KOTA BANDUNG
}

\section{Application of Universal Kriging (UK) Method for Prediction of Particulate Matter 2.5 $\left(P_{2.5}\right)$ Concentration in the City of Bandung}

\author{
Salsabila Eka Putri ${ }^{1}$, Dianne Amor Kusuma ${ }^{2}$, Bambang Suhandi ${ }^{3}$, Budi Nurani Ruchjana ${ }^{4 *}$ \\ 1,2,4 Departemen Matematika Fakultas Matematika dan Ilmu Pengetahuan Alam, Universitas Padjadjaran \\ Jalan Raya Bandung Sumedang km 21 Jatinanagor, Sumedang, 45363, Indonesia \\ ${ }^{3}$ Balai Observatorium Nasional Kupang, Desa Oelnasi, Kec. Kupang Tengah, Kab. Kupang, Nusa Tenggara Timur

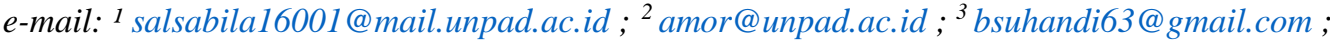 \\ 4*budi.nurani@unpad.ac.id \\ Corresponding author*
}

\begin{abstract}
Abstrak
Kecenderungan peningkatan aktifitas industri dan penduduk di Kota Bandung menimbulkan penurunan kualitas udara. Salah satu material penyebab polusi udara yang sangat berbahaya bagi kesehatan adalah particulate matter $2.5\left(\mathrm{PM}_{2.5}\right)$. Upaya pengendalian dan penanggulangan konsentrasi $\mathrm{PM}_{2.5}$ dilakukan melalui pengukuran di beberapa lokasi. Namun karena keterbatasan alat pengukur dan biaya, sehingga tidak seluruh lokasi di Kota Bandung dapat dilakukan pengukuran konsentrasi $\mathrm{PM}_{2.5}$. Data konsentrasi $\mathrm{PM}_{2.5}$ cenderung tidak stasioner. Oleh karena itu perlu dilakukan interpolasi terhadap data konsentrasi $\mathrm{PM}_{2.5}$ dengan menggunakan metode Universal Kriging. Dalam paper ini, metode Universal Kriging dapat diterapkan untuk memprediksi konsentrasi $\mathrm{PM}_{2.5} \mathrm{pada}$ lokasi yang tidak tersampel dikarenakan data konsentrasi $\mathbf{P M}_{2.5}$ yang diamati merupakan data spasial yang memiliki konsentrasi $\mathrm{PM}_{2.5}$ yang berbeda pada setiap lokasi. Data dianalisis dengan bantuan software $R$ 3.5.3 dan ArcGIS 10.4 untuk membuat peta kontur. Berdasarkan hasil prediksi konsentrasi $\mathrm{PM}_{2.5}$ pada lokasi yang tidak tersampel, diperoleh persamaan trend orde satu lebih baik digunakan untuk memprediksi konsentrasi $\mathrm{PM}_{2.5}$ dikarenakan memiliki nilai variansi eror Universal Kriging yang minimum dibandingkan persamaan trend orde dua. Hasil Penelitian menunjukkan bahwa lokasi dengan konsentrasi $\mathrm{PM}_{2.5}$ yang tinggi berada di sebelah barat laut Kota Bandung. Pada peta kontur diperlihatkan lokasi yang memiliki konsentrasi $\mathrm{PM}_{2.5}$ rendah hingga tinggi.
\end{abstract}

Kata Kunci: Kota Bandung, $\mathrm{PM}_{2.5}$, Universal Kriging, Trend (drift), Kontur.

\begin{abstract}
The tendency of increasing industrial and population activities in the city of Bandung causes a decrease in air quality. One material that causes air pollution which is very dangerous for health is particulate matter 2.5 (PM 2.5$)$. Efforts to control and overcome PM 2.5 concentration are carried out through measurements in several locations. However, due to limitations of measuring devices and costs, so not all locations in the city of Bandung can be measured PM2.5 concentration. PM2.5 concentration data tends not to be stationary. Therefore it is necessary to interpolate the PM 2.5 concentration data using the Universal Kriging method. In this paper, the Universal Kriging method can be applied to predict PM 2.5 concentrations in locations that are not sampled because the observed $P M_{2.5}$ concentration data are spatial data that have different $P M_{2.5}$ concentrations at each location. Data were analyzed with the help of software R 3.5.3 and ArcGIS 10.4 to create contour maps. Based on the prediction results of PM $M_{2.5}$ concentrations at locations that were not sampled, obtained a first order trend equation is better used to predict PM 2.5 concentrations because it has a minimum Universal Kriging error variance value compared to the second order trend equation. The results showed that the location with high $P M_{2.5}$ concentration was in the northwest of Bandung City. Contour maps show locations that have low to high PM 2.5 concentrations.
\end{abstract}

Keywords: Bandung City, PM 2.5, Universal Kriging, Trend (drift), Contour 


\section{PENDAHULUAN}

Polusi udara dapat didefinisikan sebagai kondisi atmosfir dimana konsentrasi material yang terdapat di dalamnya cukup tinggi, melebihi kondisi normal udara ambien sehingga dapat menimbulkan dampak yang terukur bagi manusia, hewan, vegetasi maupun substansi lainnya [11]. Salah satu material penyebab pencemaran udara yang sangat berbahaya bagi kesehatan adalah particulate matter $2.5\left(\mathrm{PM}_{2.5}\right) . \mathrm{PM}_{2.5}$ merupakan polutan yang berukuran kurang dari 2.5 mikrometer. Konsentrasi $\mathrm{PM}_{2.5}$ dapat melayang di udara dalam berbagai bentuk komponen dan senyawa kimia diantaranya adalah $\mathrm{Al}, \mathrm{As}, \mathrm{Br} \mathrm{Ca}, \mathrm{Cl}, \mathrm{Cu}, \mathrm{Fe}, \mathrm{K}, \mathrm{Mg}$, $\mathrm{Mn}, \mathrm{Na}, \mathrm{Ni}, \mathrm{P}, \mathrm{Pb}, \mathrm{S}, \mathrm{Si}, \mathrm{Ti}, \mathrm{V}, \mathrm{Zn}$ [10]. Sumber konsentrasi $\mathrm{PM}_{2.5}$ berasal dari kegiatan industri, asap kendaran, kebakaran hutan, pembakaran sampah, dan aktifitas lainnya yang menimbulkan polusi udara. Tingkat konsentrasi $\mathrm{PM}_{2.5}$ yang tinggi dapat menyebabkan beberapa penyakit ISPA (infeksi saluran pernafasan akut) dan kematian. Pada skala global, diperkirakan polusi udara menyebabkan lebih dari 4,2 juta kematian pada tahun 2016 [14].

Berbicara mengenai kualitas udara di Indonesia, dalam dua dekade terakhir berdasarkan penelitian yang dilakukan oleh [5] mengalami perubahan yang drastis. Konsentrasi polusi udara di Indonesia dari tahun 1998 hingga 2016 meningkat sebanyak 171 persen. Hal ini menjadikan Indonesia menjadi salah satu dari dua puluh negara tercemar di dunia.

Kota Bandung merupakan salah satu kota metropolitan terbesar di Jawa Barat dan berdasarkan data dari Badan Pusat Satistik (BPS) jumlah penduduk, industri, dan kendaraan mengalami peningkatan setiap tahunnya [2]. Kecenderungan peningkatan aktifitas penduduk dan industri di Kota Bandung menimbulkan penurunan kualitas udara. Berdasarkan data AQMS (Air Quality Monitoring System) konsentrasi $\mathrm{PM}_{2.5}$ di Kota Bandung mencapai angka 127 AQI dengan status unhealthy for sensitive group. Hal ini menunjukkan perlunya perhatian lebih dari pemerintah untuk bertindak dalam menangani polusi udara.

Upaya untuk meningkatkan efektifitas dalam penanggulangan masalah pencamaran udara khususnya konsentrasi $\mathrm{PM}_{2.5}$ adalah dengan cara memberikan perhatian lebih pada lokasi yang kadar pencemarannya tinggi. Namun, karena keterbatasan alat pengukur dan biaya yang mahal, sehingga tidak seluruh lokasi di Kota Bandung dapat dilakukan pengukuran dan pengujian konsentrasi $\mathbf{P M}_{2.5}$. Oleh karena itu dibutuhkan metode untuk memprediksi konsentrasi $\mathrm{PM}_{2.5}$ di lokasi yang tidak tersampel.

Kriging adalah suatu metode pengestimasian variabel teregionalisasi (regionalized variable), dimana variabel tersebut dapat memiliki nilai yang berbeda sesuai dengan berubahnya lokasi atau tempat. Metode Kriging dapat dibedakan dalam beberapa macam, yaitu: Simple Kriging, Ordinary Kriging, Universal Kriging dan Co-Kriging. Metode Universal Kriging merupakan metode Kriging yang memiliki asumsi data tidak harus stasioner. Beberapa penelitian sebelumnya yang meneliti polusi udara dengan metode Kriging diantaranya, [6] memprediksi konsentrasi particulate matter di 7 kota Korea Selatan dengan menggunakan metode Ordinary Kriging. Selanjutnya [9] melakukan penerapan metode Ordinary Kriging pada pendugaan kadar $\mathrm{NO}_{2}$ di udara. Sedangkan [4] melakukan penerapan metode Universal Kriging untuk memprediksi polutan menggunakan GSTAT R. Selanjutnya penelitian mengenai konsentrasi $\mathrm{PM}_{2.5}$ dan $\mathrm{NO}_{2}$ di Tiongkok dengan membandingkan metode regresi, pengukuran satelit, dan Universal Kriging [13].

Data konsentrasi $\mathrm{PM}_{2.5}$ memiliki kecenderungan tidak stasioner dalam rata-rata, sehingga berdasarkan uraian penggunaan metode Kriging yang telah dilakukan para peneliti terdahulu, maka pada penelitian ini penulis menganalisis data spasial konsentrasi $\mathrm{PM}_{2.5}$ di Kota Bandung menggunakan metode Universal Kriging untuk memprediksi pengamatan di lokasi tidak tersampel. Pada penelitian ini diprediksi konsentrasi $\mathrm{PM}_{2.5}$ pada lokasi yang tidak tersampel di wilayah Kota Bandung menggunakan metode Universal Kriging dengan persamaan trend orde satu dan orde dua. Data hasil prediksi digunakan untuk membuat peta kontur sehingga dapat diketahui lokasi mana yang memerlukan perhatian khusus.

\section{METODE PENELITIAN}

\subsection{Semivariogram}

Semivariogram adalah suatu perangkat untuk menggambarkan, memodelkan, dan menghitung korelasi spasial antara variabel random $Z\left(x_{i}\right)$ dan $Z\left(x_{i}+h\right)[1]$. 


\subsubsection{Semivariogram Eksperimental}

Semivariogram eksperimental adalah semivariogram yang diperoleh dari data yang diamati atau data hasil pengukuran. Taksiran semivariogram eksperimental pada jarak $h$, dapat dituliskan sebagai berikut [1]:

$$
\hat{\gamma}(h)=\frac{1}{2 N(h)} \sum_{i=1}^{N(h)}\left[Z\left(x_{i}+h\right)-Z\left(x_{i}\right)\right]^{2}
$$

dengan:

$\hat{\gamma}(h) \quad$ : Nilai semivariogram pada jarak $h$

$Z\left(x_{i}\right) \quad$ : Nilai pengamatan di lokasi $x$

$Z\left(x_{i}+h\right) \quad$ : Nilai pengamatan di lokasi $x+h$

$N(h) \quad$ : Banyaknya pasangan titik yang mempunyai jarak $h$

\subsubsection{Semivariogram Teoretis}

Model semivariogram teoretis yang digunakan yaitu [1]:

1. Model Spherical

$$
\gamma(h)=\left\{\begin{array}{cc}
c\left[\left(\frac{3 h}{2 a}\right)\right. & \left.-\left(\frac{h^{3}}{2 a^{3}}\right)\right], \quad h \leq a \\
c, & h>a
\end{array}\right.
$$

2. Model Exponential

3. Model Gaussian

$$
\gamma(h)=\left\{\begin{array}{c}
c\left[1-\exp \left(\frac{-h}{a}\right)\right], \quad h \leq a \\
c, h>a
\end{array}\right.
$$

$$
\gamma(h)=\left\{\begin{array}{c}
c\left[1-\exp \left(\frac{-h^{2}}{a^{2}}\right)\right], \quad h \leq a \\
c, \quad h>a
\end{array}\right.
$$

dengan:

$h:$ Jarak antar dua lokasi

$c:$ Sill

$a:$ Range

\subsection{Metode Universal Kriging}

Metode Universal Kriging merupakan metode Kriging dengan asumsi rata-rata (mean) tidak konstan dan data yang mempunyai kecenderungan trend (drift) tertentu [7]. Estimator Universal Kriging $\hat{Z}\left(x_{0}\right)$ untuk fungsi random $Z\left(x_{i}\right)$ adalah

$$
\hat{Z}\left(x_{0}\right)=\sum_{i=1}^{k} \lambda_{i} Z\left(x_{i}\right)
$$

jika $m(x)$ adalah persamaan trend (drift), dengan persamaan sebagai berikut:

$$
m(x)=\sum_{l=0}^{n} a_{l} f_{l}(x)
$$

dengan:

$a_{l} \quad:$ koefisien trend

$f_{l}(x) \quad$ : koordinat lokasi

$n \quad$ : banyaknya orde dalam persamaan trend.

Penaksir atau estimator Universal Kriging memiliki sifat: 
a. Linear

Estimator Universal Kriging yang diperoleh dari $n$ observasi data yang digunakan membentuk model linear, yaitu:

$$
\hat{Z}\left(x_{0}\right)=\sum_{i=1}^{k} \lambda_{i} Z\left(x_{i}\right)
$$

\section{b. Unbiased}

Estimator Universal Kriging bersifat tak bias jika memenuhi persamaan $E\left[\hat{Z}\left(x_{0}\right)-Z\left(x_{0}\right)\right]=0$. Menurut [7] estimator Universal Kriging akan bersifat sebagai estimator yang tak bias jika dan hanya jika:

$$
\sum_{i=1}^{k} \lambda_{i} f_{l}\left(x_{i}\right)=f_{l}\left(x_{0}\right) \text { untuk } l=0,1, \ldots, n
$$

c. Best

Best adalah estimator Universal Kriging memiliki variansi estimator minimum. Persamaan variansi estimator adalah sebagai berikut:

$$
\sigma^{2}\left(x_{0}\right)=2 \sum_{i=1}^{k} \lambda_{i} \gamma_{Y}\left(x_{0}-x_{i}\right)-\sum_{i=1}^{k} \sum_{j=1}^{k} \lambda_{i} \lambda_{j} \gamma_{Y}\left(x_{i}-x_{j}\right) .
$$

Untuk memperoleh nilai minimum dari variansi error menggunakan Lagrange Multiplier dengan parameter Lagrange $\mu_{l}$. Persamaan Lagrange Multiplier untuk Universal Kriging dinyatakan sebagai berikut [7]:

$$
L\left(\lambda_{i}, \mu_{l}\right)=\sigma^{2}\left(x_{0}\right)+2 \mu_{0}\left(\sum_{i=1}^{k} \lambda_{i}-1\right)+2 \sum_{l=1}^{n} \mu_{l}\left(\sum_{i=1}^{k} \lambda_{i} f_{l}\left(x_{i}\right)-f_{l}\left(x_{0}\right)\right)
$$

Bentuk matriks untuk penyelesaian metode Universal Kriging adalah sebagai berikut:

$$
\cdot\left[\begin{array}{c}
\lambda_{1} \\
\lambda_{2} \\
\vdots \\
\lambda_{k} \\
\mu_{0} \\
\mu_{1} \\
\mu_{2} \\
\vdots \\
\mu_{n}
\end{array}\right]=\left[\begin{array}{ccccccccc}
\gamma_{Y}\left(x_{1}-x_{1}\right) & \gamma_{Y}\left(x_{2}-x_{1}\right) & \cdots & \gamma_{Y}\left(x_{k}-x_{1}\right) & 1 & f_{1}\left(x_{1}\right) & f_{2}\left(x_{1}\right) & \cdots & f_{n}\left(x_{1}\right) \\
\gamma_{Y}\left(x_{1}-x_{2}\right) & \gamma_{Y}\left(x_{2}-x_{2}\right) & \cdots & \gamma_{Y}\left(x_{k}-x_{2}\right) & 1 & f_{1}\left(x_{2}\right) & f_{2}\left(x_{2}\right) & \cdots & f_{n}\left(x_{2}\right) \\
\vdots & \vdots & \ddots & \vdots & \vdots & \vdots & \vdots & \ddots & \vdots \\
\gamma_{Y}\left(x_{1}-x_{k}\right) & \gamma_{Y}\left(x_{2}-x_{k}\right) & \cdots & \gamma_{Y}\left(x_{k}-x_{k}\right) & 1 & f_{1}\left(x_{k}\right) & f_{2}\left(x_{k}\right) & \cdots & f_{n}\left(x_{k}\right) \\
1 & 1 & \cdots & 1 & 0 & 0 & 0 & \cdots & 0 \\
f_{1}\left(x_{1}\right) & f_{1}\left(x_{2}\right) & \cdots & f_{1}\left(x_{k}\right) & 0 & 0 & 0 & \cdots & 0 \\
f_{2}\left(x_{1}\right) & f_{2}\left(x_{2}\right) & \cdots & f_{2}\left(x_{k}\right) & 0 & 0 & 0 & \cdots & 0 \\
\vdots & \vdots & \ddots & \vdots & \vdots & \vdots & \vdots & \ddots & \vdots \\
f_{n}\left(x_{1}\right) & f_{n}\left(x_{2}\right) & \cdots & f_{n}\left(x_{k}\right) & 0 & 0 & 0 & \cdots & 0
\end{array}\right]^{-1}\left[\begin{array}{c}
\gamma_{Y}\left(x_{0}-x_{1}\right) \\
\gamma_{Y}\left(x_{0}-x_{2}\right) \\
\vdots \\
\gamma_{Y}\left(x_{0}-x_{k}\right) \\
1 \\
f_{1}\left(x_{0}\right) \\
f_{2}\left(x_{0}\right) \\
\vdots \\
f_{n}\left(x_{0}\right)
\end{array}\right]
$$

dengan:

$\gamma_{Y}\left(x_{i}-x_{j}\right) \quad$ : semivariogram antar titik-titik tersampel

$\gamma_{Y}\left(x_{0}-x_{i}\right) \quad$ : semivariogram antar titik-titik tersampel dengan titik ekstrim

$f_{l}\left(x_{i}\right), f_{l}\left(x_{j}\right) \quad$ : koordinat lokasi dari data tersampel

$\left(x_{i}, x_{j}\right) \quad:$ lokasi dari data tersampel

$\lambda_{i} \quad:$ bobot $Z\left(x_{i}\right)$ untuk prediksi lokasi $x_{0}$

$\mu_{l} \quad$ : nilai dari parameter Lagrange

$x_{0} \quad:$ lokasi data yang akan diestimasi

$n \quad$ : banyaknya order dalam persamaan trend.

Pada penelitian ini persamaan trend (drift) yang digunakan adalah sebagai berikut [7]:

Persamaan trend (drift) orde satu di $D \subset R^{2}$ adalah sebagai berikut:

$$
m(x)=m\left(x_{i}, y_{i}\right)=a_{0}+a_{1} x_{i}+a_{2} y_{i}
$$

Persamaan trend (drift) orde dua di $D \subset R^{2}$ adalah sebagai berikut:

$$
m(x)=m\left(x_{i}, y_{i}\right)=a_{0}+a_{1} x_{i}+a_{2} y_{i}+a_{3} x_{i}^{2}+a_{4} y_{i}^{2}+a_{1} x_{i} y_{i}
$$


Contoh grafik persamaan trend sebagai berikut:

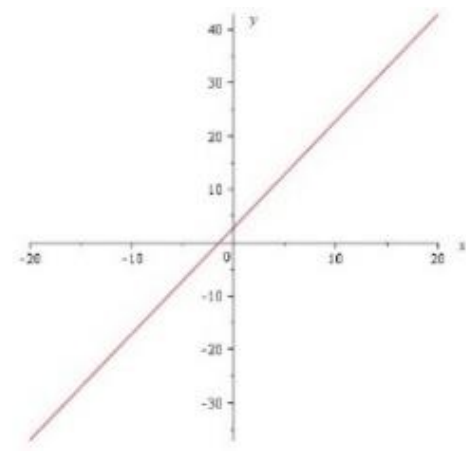

(a) Orde Satu

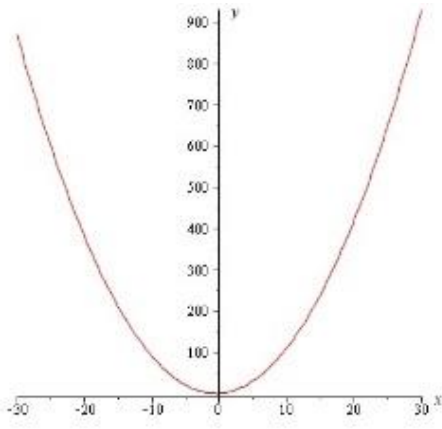

(b) Orde Dua

Gambar 1. Grafik Polinomial Berorde Satu dan Dua

\subsection{Objek Penelitian}

Data yang digunakan dalam penelitian ini adalah data sekunder mengenai polusi udara, yaitu data konsentrasi $\mathrm{PM}_{2.5}$ di Kota Bandung pada tahun 2014 yang diperoleh dari Badan Pengelolaan Lingkungan Hidup (BPLH). Data yang ada di lembaga tersebut untuk tahun yang terdekat tidak selengkap data tahun 2014. Mengingat yang akan dianalisis adalah data spasial di lokasi-lokasi wilayah Kota Bandung, maka pemilihan data temporal 2014 tetap dapat digunakan untuk penerapan Metode Universal Kriging. Data tersebut berjumlah 25 lokasi tersampel yang terdiri dari $(x, y)$ koordinat lokasi dan konsentrasi $\mathrm{PM}_{2.5}$ di udara. Variabel penelitian yang digunakan adalah:

$x \quad$ : Titik koordinat easting

$y \quad$ : Titik koordinat northing

$\mathrm{PM}_{2.5} \quad$ : Konsentrasi $\mathrm{PM}_{2.5}$ di udara $\left(\mu \mathrm{g} / \mathrm{m}^{3}\right)$

\subsection{Tahap Analisis Data}

Tahap analisis data yang dilakukan adalah sebagai berikut:

1. Melakukan input data konsentari $\mathbf{P M}_{2.5}$ di Kota Bandung.

2. Memeriksa kestasioneran data dengan menggunakan plot konsentrasi $\mathbf{P M}_{2.5}$ terhadap easting dan northing. Pada tahap ini, data dicek apakah stasioner atau tidak. Jika data stasioner artinya derajat trend nol, sebenarnya masih dapat digunakan metode Universal Kriging. Namun ada umumnya metode Universal Kriging digunakan untuk derajat trend 1 atau lebih. Dengan kata lain umumnya data bersifat tidak stasioner [7].

3. Menghitung persamaan trend dengan mengunakan model linear. Pada penelitian ini persamaan trend yang digunakan adalah persamaan trend orde satu dan orde dua dari data konsentrasi $\mathrm{PM}_{2.5}$ [3].

4. Menghitung semivariogram eksperimental dengan menggunakan persamaan (1). Semivariogram eksperimental digunakan untuk menggambarkan, memodelkan, dan menghitung korelasi spasial dari data yang diamati [1]. Perhitungan semivariogram eksperimental dibantu dengan menggunakan software $R$.

5. Mencocokkan model semivariogram eksperimental dengan model semivariogram teoretis untuk mendapatkan model semivariogram yang paling sesuai dengan data. Mencari model Semivariogram teoretis menggunakan persamaan (2), (3), dan (4). Model semivariogram teoretis yang paling cocok dengan data dipilih berdasarkan nilai Sum of Squared Errors (SSE) yang paling minimum [7].

6. Memprediksi konsentari $\mathbf{P M}_{2.5}$ pada lokasi yang tersampel di Kota Bandung untuk melihat akurasi dari prediksi yang dilakukan dengan metode Universal Kriging. Setelah hasil prediksi pada lokasi yang tersampel didapat, maka langkah selanjutnya adalah memprediksi konsentrasi $\mathrm{PM}_{2.5}$ pada lokasi yang tidak tersampel.

7. Membuat peta kontur berdasarkan hasil prediksi yang diperoleh dengan bantuan software ArcGIS 10.4 . 


\section{HASIL DAN PEMBAHASAN}

\subsection{Statistika Deskriptif Data Konsentrasi $\mathbf{P M}_{2.5}$}

Data yang digunakan dalam penelitian ini sebanyak 25 data konsentrasi $\mathrm{PM}_{2.5}$ di Kota Bandung. Perhitungan dengan bantuan software $\mathrm{R}$, didapat statistika deskriptif sebagai berikut:

Tabel 1. Statistika Deskriptif Data Konsentrasi PM2.5

\begin{tabular}{|cccc|}
\hline & $\begin{array}{c}\text { Easting } \\
(\mathrm{x})\end{array}$ & $\begin{array}{c}\text { Northing } \\
(\mathrm{y})\end{array}$ & $\begin{array}{c}\mathrm{PM}_{2.5} \\
\left(\mu \mathrm{g} / \mathrm{m}^{3}\right)\end{array}$ \\
\hline Minimum & 784525 & 9230982 & 20,00 \\
$\mathbf{1}^{\text {st }}$ Quartil & 787856 & 9232343 & 34,00 \\
Median & 789118 & 9235767 & 42,00 \\
Mean & 790079 & 9235299 & 42,96 \\
3 $^{\text {rd }}$ Quartil & 792828 & 9237045 & 49,00 \\
Maximum & 800298 & 9241130 & 75,00 \\
Variansi & - & - & 197,7067 \\
\hline
\end{tabular}

Berdasarkan Tabel 1, terlihat bahwa nilai rata-rata konsentrasi $\mathrm{PM}_{2.5}$ di Kota Bandung cukup tinggi yaitu, sebesar $42,96 \mu \mathrm{g} / \mathrm{m}^{3}$ dengan status unhealthy for sensitive group. Konsentrasi minimum $\mathrm{PM}_{2.5}$ terdapat di Jl. Barisan Keamanan Rakyat (BKR) sebesar 20,00 $\mu \mathrm{g} / \mathrm{m}^{3}$. Hal ini menunjukkan kemungkinan pengambilan sampel konsentrasi $\mathrm{PM}_{2.5}$ di Jl. BKR merupakan kawasan dengan aktifitas industri dan kepadatan lalu lintas yang rendah. Konsentrasi maksimum $\mathrm{PM}_{2.5}$ terdapat di Terminal Ledeng sebesar 75,00 $\mu \mathrm{g} / \mathrm{m}^{3}$. Hal ini menunjukkan tingginya aktifitas yang memicu tingginya konsentrasi $\mathrm{PM}_{2.5}$ seperti kepadatan lalu lintas, aktifitas insdutri, dan lain-lain.

\subsection{Kestasioneran Data Konsentrasi $\mathbf{P M}_{2.5}$}

Pada Ordinary Kriging diperlukan asumsi data bersifat stasioner orde dua, sedangkan pada Universal Kriging stasioner orde dua tidak berlaku [7], sehingga dilakukan plotting data konsentrasi $\mathrm{PM}_{2.5}$ terhadap easting dan northing untuk melihat apakah data stasioner atau tidak. Gambar 3 memperlihatkan plotting data konsentrasi $\mathrm{PM}_{2.5}$.
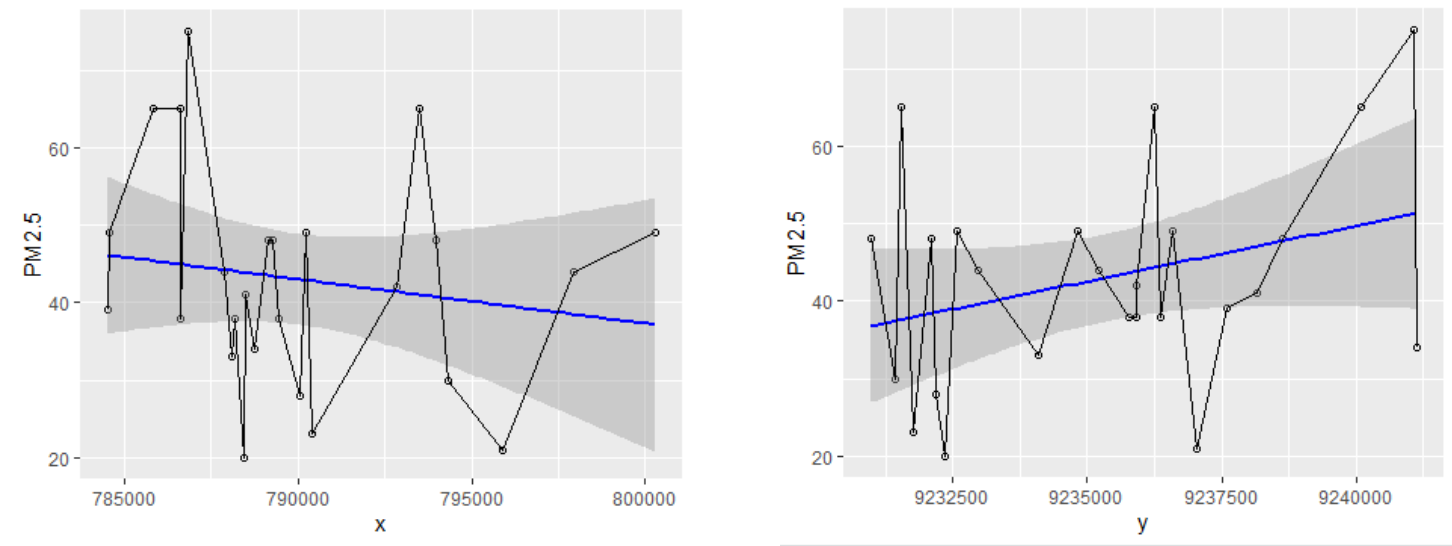

Gambar 3. Plot Konsentrasi PM2.5 Berdasarkan Easting dan Northing

Hasil plot pada Gambar 3 terlihat bahwa data konsentrasi $\mathrm{PM}_{2.5}$ memiliki kecenderungan trend (drift). Hal tersebut menunjukan bahwa data konsentrasi $\mathrm{PM}_{2.5}$ di Kota Bandung tidak stasioner, sehingga data tersebut dapat dianalisis dengan menggunakan metode Universal Kriging.

\subsection{Menentukan Persamaan Trend (Drift)}

Universal kriging merupakan metode kriging dari data yang memiliki kecenderungan trend (drift) tertentu. Pada penelitian ini orde dari persamaan trend (drift) dibatasi yaitu orde satu dan orde dua. Perhitungan dengan bantuan software R Studio, didapat koefisien dari persamaan trend (drift) sebagai berikut: 
Tabel 2. Koefisien Persamaan Trend (Drift) Orde Satu

\begin{tabular}{|ccc|}
\hline \multicolumn{3}{|c|}{ Koefisien } \\
\hline Intercept & $x$ & $y$ \\
\hline-11970 & $-0,0002876$ & 0,001326 \\
\hline
\end{tabular}

Berdasarkan Tabel 2 diperoleh hasil dari persamaan trend (drift) berorde satu sebagai berikut:

$$
m(x, y)=-11970-0,000287 x+0,00132 y
$$

Pada persamaan trend (drift) orde satu, $\mathrm{m}(\mathrm{x}, \mathrm{y})$ merupakan konsentrasi $\mathrm{PM}_{2.5}$ dan $\mathrm{x}$ adalah koordinat easting, sedangkan y adalah koordinat northing, artinya ketika nilai $\mathrm{x}$ sama dengan nol dan nilai y sama dengan nol, maka konsentrasi $\mathrm{PM}_{2.5}$ akan sama sengan nilai intercept. Jika nilai $\mathrm{x}$ bertambah satu satuan maka maka konsentrasi $\mathrm{PM}_{2.5}$ akan berkurang sebesar 0,000287 , sedangkan jika nilai y bertambah satu satuan maka maka konsentrasi $\mathrm{PM}_{2.5}$ akan bertambah sebesar 0,00132.

Tabel 3. Koefisien Persamaan Trend (Drift) Orde Dua

\begin{tabular}{|cccccc|}
\hline \multicolumn{5}{c|}{ Koefisien } \\
\hline Intercept & $x$ & $y$ & $x^{2}$ & $y^{2}$ & $x y$ \\
\hline $2,66 \times 10^{7}$ & $-2,95 \times 10^{-2}$ & $-5,75$ & $1,92 \times 10^{-7}$ & $3,13 \times 10^{-7}$ & $-2,98 \times 10^{-8}$ \\
\hline
\end{tabular}

Berdasarkan Tabel 3 diperoleh hasil dari persamaan trend (drift) berorde dua sebagai berikut:

$$
\begin{aligned}
m(x, y)= & \left(2,66 \times 10^{7}\right)-\left(2,95 \times 10^{-2}\right) x-5,75 y+\left(1,92 \times 10^{-7}\right) x^{2}+\left(3,13 \times 10^{-7}\right) y^{2}-(2,98 \times \\
& \left.10^{-8}\right) x y
\end{aligned}
$$

Pada persamaan trend (drift) orde dua, $\mathbf{n}(\mathbf{x}, \mathbf{y})$ merupakan konsentrasi $\mathrm{PM}_{2.5}$ dan $\mathbf{x}$ adalah koordinat easting, sedangkan $\mathbf{y}$ adalah koordinat northing, artinya ketika nilai $\mathbf{x}, \mathbf{y}, \mathbf{x}^{2}, \mathbf{y}^{2}$ dan $\mathbf{x y}$ sama dengan nol, maka konsentrasi $\mathbf{P M}_{2.5}$ akan sama dengan nilai intercept. Jika nilai $\mathbf{x}$ bertambah satu satuan maka maka konsentrasi $\mathrm{PM}_{2.5}$ akan berkurang sebesar $2,95 \times \mathbf{1 0}^{-\mathbf{2}}$, jika nilai $\mathbf{y}$ bertambah satu satuan maka maka konsentrasi $\mathrm{PM}_{2.5}$ akan berkurang sebesar 5,75, jika nilai $\mathbf{x}^{2}$ bertambah satu satuan maka maka konsentrasi $\mathrm{PM}_{2.5}$ akan bertambah sebesar $1,92 \times \mathbf{1 0}^{-\mathbf{7}}$, jika nilai $\mathbf{y}^{\mathbf{2}}$ bertambah satu satuan maka maka konsentrasi $\mathrm{PM}_{2.5}$ akan bertambah sebesar $3,13 \times \mathbf{1 0}^{-\mathbf{7}}$, dan jika nilai xy bertambah satu satuan maka maka konsentrasi $\mathrm{PM}_{2.5}$ akan berkurang sebesar $-2,98 \times \mathbf{1 0}^{-\mathbf{8}}$.

\subsection{Semivariogram Eksperimental}

Nilai semivariogram eksperimental atau sering disebut $\gamma(h)$ dihitung berdasarkan semua pasangan jarak yang mungkin dimana fungsi jarak yang digunakan adalah jarak Euclidean, dengan menggunakan persamaan (1) dapat diperoleh nilai semivariogram beserta banyaknya pasangan jarak. Pada penelitian ini data konsentrasi $\mathrm{PM}_{2.5}$ yang tersampel terdiri dari 25 lokasi sehingga membuat proses perhitungan secara manual untuk nilai semivariogram eksperimental konsentrasi $\mathrm{PM}_{2.5}$ menjadi sulit. Perhitungan semivariogram eksperimental dengan bantuan software R Studio sebagai berikut: 
Tabel 4. Nilai Semivariogram Beserta Pasangan Data dan Jaraknya

\begin{tabular}{|c|c|c|c|}
\hline No & Banyaknya pasangan data yang berjarak sama & Jarak (m) & $\begin{array}{c}\text { Semivariogram } \\
\text { Eksperimental } \mathrm{PM}_{2.5}\end{array}$ \\
\hline 1 & 5 & 724,1058 & 98,89491 \\
\hline 2 & 2 & 1012,2549 & 170,77238 \\
\hline 3 & 7 & 1474,8394 & 155,30337 \\
\hline 4 & 7 & 1935,1288 & 311,6633 \\
\hline 5 & 9 & 2292,9559 & 38,10753 \\
\hline 6 & 13 & 2736,5427 & 167,09706 \\
\hline 7 & 12 & 3153,8177 & 180,24385 \\
\hline 8 & 10 & 3519,9141 & 211,68195 \\
\hline 9 & 16 & 3934,9342 & 164,27715 \\
\hline 10 & 9 & 4318,7915 & 125,51119 \\
\hline 11 & 22 & 4769,4213 & 127,09749 \\
\hline 12 & 20 & 5226,8506 & 210,92228 \\
\hline 13 & 20 & 5653,0663 & 181,31619 \\
\hline 14 & 14 & 6089,4098 & 80,14284 \\
\hline
\end{tabular}

Tabel 4 memperlihatkan bahwa dari 25 lokasi tersampel terdapat 14 kriteria banyaknya pasangan data yang berjarak sama dan memiliki nilai semivariogram setiap jaraknya. Selanjutnya diperoleh plot yang dapat dilihat pada Gambar 4. dari nilai semivariogram eksperimental $\gamma(h)$ terhadap jaraknya $(h)$.

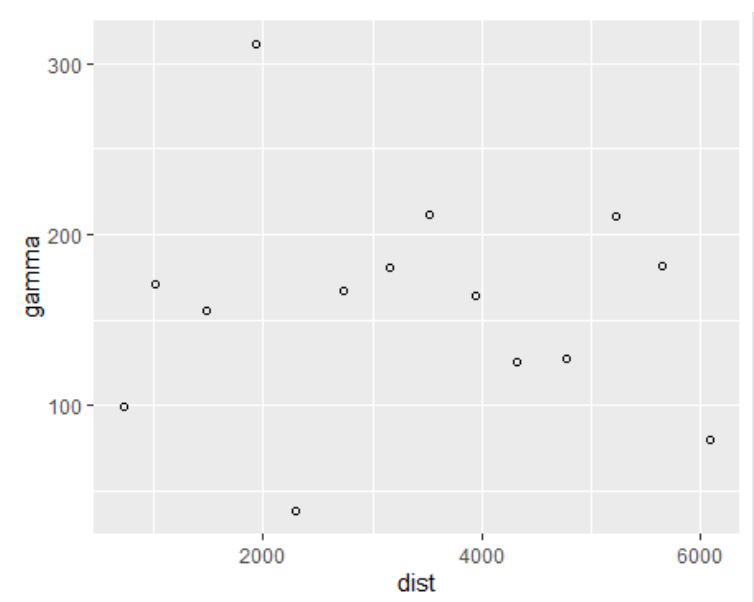

Gambar 4. Semivariogram Eksperimental

Dari Gambar 4 selanjutnya dilakukan pemilihan model semivariogram teoretis yang terbaik dengan cara yang fitting model semivariogram teoretis yang sesuai dengan semivariogram pada Gambar 4.

\subsection{Fitting Model Semivariogram Teoretis}

Tahap pertama dalam fitting model semivariogram teoretis adalah menentukan model dasar semivarigram teoretis. Model semivariogram teoretis yang digunakan pada penelitian ini yaitu model semivariogram teoretis spherical, eksponensial, dan gaussian. Dengan bantuan software R Studio, didapat ketiga model semivariogram teoretis untuk data konsentrasi $\mathrm{PM}_{2.5}$ sebagai berikut: 


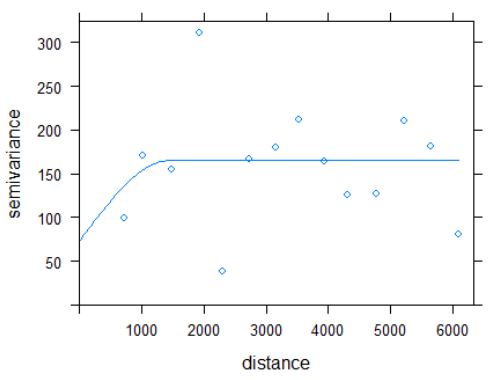

(a) Spherical

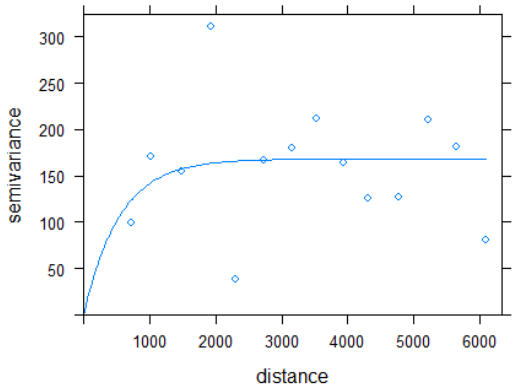

(b) Eksponensial

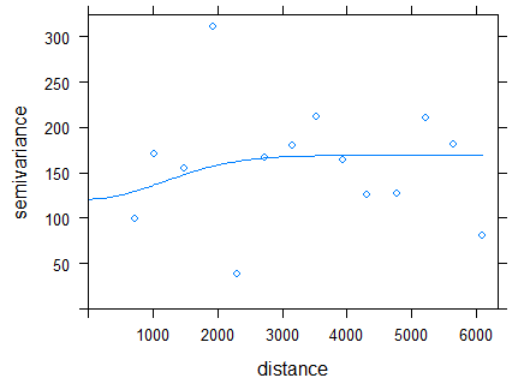

(c) Gaussian

Gambar 5. Semivariogram Teoretis

Selanjutnya didapat nilai nugget effect sill dan range dari model semivariogram teoretis sebagai berikut:

Tabel 5. Nilai Nugget Effect, Sill dan Range Model Semivariogram Teoretis

\begin{tabular}{|cccc|}
\hline Model & Nugget effect & Sill & Range \\
\hline Spherical & 72,847 & 91,998 & 1433,085 \\
Eksponensial & 0 & 168,210 & 541,39 \\
Gaussian & 120,908 & 48,267 & 1637,165 \\
\hline
\end{tabular}

\subsection{Penentuan Model Semivariogram Terbaik}

Model semivariogram terbaik diperoleh dengan menghitung Sum of Squared Errors (SSE) disetiap lag. Besarnya error diperoleh dari selisih nilai semivariogram eksperimental dengan nilai semivariogram teoretis di setiap lag. Hasil nilai error dari model semivariogram adalah sebagai berikut:

Tabel 6 Perhitungan Sum of Squared Errors (SSE) Model Semivariogram

\begin{tabular}{|cc|}
\hline \multicolumn{2}{|c|}{ SSE Model Semivariogram } \\
\hline Model & Nilai \\
\hline Spherical & 0,01414573 \\
Eksponensial & 0,01186995 \\
Gaussian & 0,01250706 \\
\hline
\end{tabular}

Berdasarkan Tabel 6 dari ketiga model semivariogram teoretis tersebut, terlihat bahwa model semivariogram teoretis terbaik yang dipilih adalah model semivariogram eksponensial, karena memiliki nilai Sum of Squared Errors (SSE) paling minimum diantara model semivariogram spherical dan gaussian, karena semakin kecil nilai SSE maka semakin baik model tersebut, dengan nilai SSE sebesar 0,01186995.

\subsection{Penerapan Metode Universal Kriging Untuk Prediksi Konsentrasi PM$_{2.5}$}

Data yang diprediksi sebanyak 10 lokasi yang sebelumnya telah diketahui lokasi sampelnya dengan asumsi lokasi tersebut tidak tersampel. Data hasil prediksi kemudian dibandingkan dengan data konsentrasi $\mathrm{PM}_{2.5}$ yang tersampel untuk mencari nilai residual pada masing-masing persamaan orde trend. Nilai residual dapat dilihat pada Tabel 7 dan Tabel 8. 
Tabel 7. Hasil Prediksi dan Residual Konsentrasi PM2.5 pada Lokasi tersampel Orde Satu

\begin{tabular}{|ccccc|}
\hline No & Koordinat & $\begin{array}{c}\mathrm{PM}_{2.5} \\
\left(\mu \mathrm{g} / \mathrm{m}^{3}\right)\end{array}$ & $\begin{array}{c}\text { Prediksi } \mathrm{PM}_{2.5} \\
\left(\mu \mathrm{g} / \mathrm{m}^{3}\right)\end{array}$ & Residual \\
\hline 1 & $(794319.6,9231427)$ & 30 & 30,00652 & 0,0000425 \\
2 & $(785819.1,9240091)$ & 65 & 64,99670 & 0,0000109 \\
3 & $(795880.9,9237045)$ & 21 & 21,00527 & 0,0000278 \\
4 & $(797935.2,9235203)$ & 44 & 43,99862 & 0,0000019 \\
5 & $(786612.8,9231531$ & 65 & 64,99092 & 0,0000824 \\
6 & $(786808.6,9241060)$ & 75 & 74,98005 & 0,0003980 \\
7 & $(793507.6,9236250)$ & 65 & 64,98232 & 0,0003126 \\
8 & $(788090.4,9234099)$ & 33 & 33,00810 & 0,0000656 \\
9 & $(784524.7,9237596)$ & 39 & 39,00532 & 0,0000283 \\
10 & $(788158.3,9235909)$ & 38 & 38,00317 & 0,0000100 \\
\hline \multicolumn{5}{c}{ Sum of Squared Errors (SSE) } \\
\hline
\end{tabular}

Tabel 8. Hasil Prediksi dan Residual Konsentrasi PM2.5 pada Lokasi tersampel Orde Dua

\begin{tabular}{|ccccc|}
\hline No & Koordinat & $\begin{array}{c}\mathrm{PM}_{2.5} \\
\left(\mu \mathrm{g} / \mathrm{m}^{3}\right)\end{array}$ & $\begin{array}{c}\text { Prediksi } \mathrm{PM}_{2.5} \\
\left(\mu \mathrm{g} / \mathrm{m}^{3}\right)\end{array}$ & Residual \\
\hline 1 & $(794319.6,9231427)$ & 30 & 30,01022 & 0,0001044 \\
2 & $(785819.1,9240091)$ & 65 & 64,99802 & 0,0000039 \\
3 & $(795880.9,9237045)$ & 21 & 21,00361 & 0,0000130 \\
4 & $(797935.2,9235203)$ & 44 & 43,99773 & 0,0000052 \\
5 & $(786612.8,9231531$ & 65 & 64,98997 & 0,0001006 \\
6 & $(786808.6,9241060)$ & 75 & 74,98200 & 0,0003240 \\
7 & $(793507.6,9236250)$ & 65 & 64,97961 & 0,0004158 \\
8 & $(788090.4,9234099)$ & 33 & 33,00737 & 0,0000543 \\
9 & $(784524.7,9237596)$ & 39 & 39,00706 & 0,0000498 \\
10 & $(788158.3,9235909)$ & 38 & 38,00301 & 0,0000091 \\
\hline \multicolumn{5}{c}{ Sum of Squared Errors (SSE) } \\
\hline
\end{tabular}

Berdasarkan Tabel 7 dan Tabel 8 diperoleh nilai residual dari data sampel dan data prediksi di 10 lokasi sampel dengan asumsi tidak tersampel. Nilai SSE yang diperoleh untuk orde satu sebesar 0,00098007 dan untuk orde dua sebesar 0,00108. Persamaan trend orde satu memiliki nilai SSEl yang lebih kecil dibandingkan persamaan trend orde dua, sehingga metode Universal Kringing menggunakan persamaan trend orde satu lebih akurat digunakan untuk memprediksi konsentrasi $\mathrm{PM}_{2.5}$.

Setelah melakukan prediksi pada lokasi tersampel dan hasilnya mendekati nilai sebenarnya dengan koefisien korelasi yang sangat kuat sebesar $99,97 \%$, selanjutnya diprediksi konsentrasi $\mathrm{PM}_{2.5}$ pada lokasi yang tidak tersempel. Banyaknya lokasi yang diprediksi konsentrasi $\mathbf{P M}_{2.5}$ di Kota Bandung adalah 69 lokasi. Lokasi yang diprediksi konsentrasi $\mathrm{PM}_{2.5}$ ditunjukkan pada Gambar 6, sebagai berikut: 


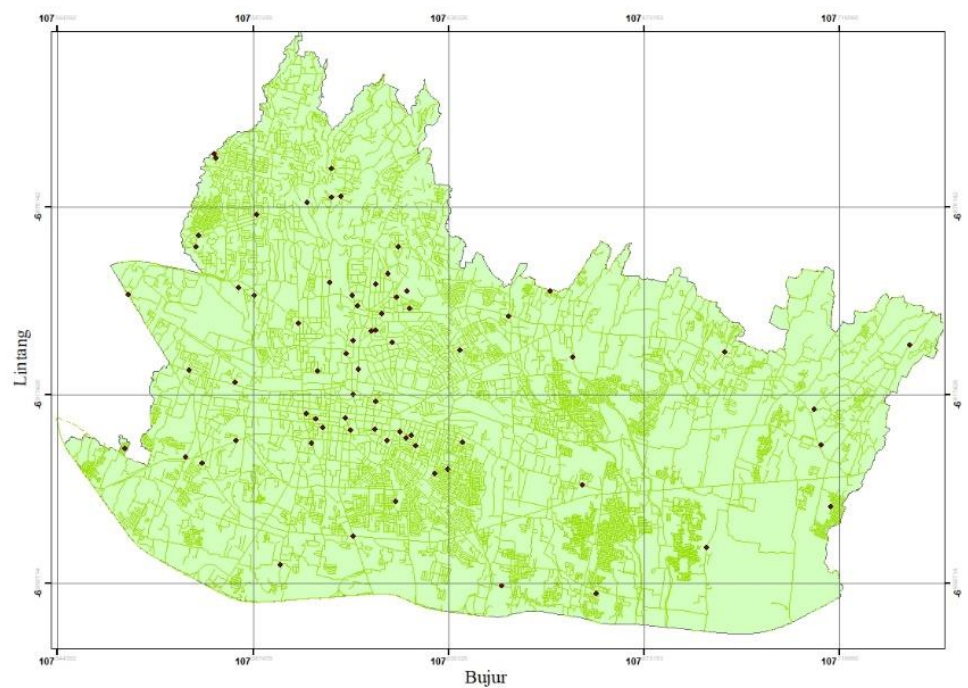

Gambar 6 Peta Lokasi Prediksi Konsentrasi PM2.5 di Kota Bandung

Statistika deskriptif dari hasil prediksi konsentrasi $\mathrm{PM}_{2.5}$ pada lokasi yang tidak tersampel dapat dilihat sebagai berikut:

Tabel 9. Statistika Deskriptif Hasil Prediksi Konsentrasi PM2.5 pada Lokasi Tidak Tersampel

\begin{tabular}{|ccc|}
\hline & \multicolumn{2}{c|}{$\mathrm{PM}_{2.5}\left(\mu \mathrm{g} / \mathrm{m}^{3}\right)$} \\
\cline { 2 - 3 } & Orde Satu & Orde Dua \\
\hline Minimum & 34,56 & 33,62 \\
$\mathbf{1}^{\text {st } \text { Quartil }}$ & 39,65 & 39,42 \\
Median & 42,17 & 41,21 \\
Mean & 42,58 & 42,78 \\
$\mathbf{3}^{\text {rd } \text { Quartil }}$ & 44,93 & 45,11 \\
Maximum & 54,35 & 59,79 \\
Rata-rata Variansi Eror & 167,22 & 172,7 \\
Universal Kriging & & \\
\hline
\end{tabular}

Tabel 9 memperlihatkan bahwa hasil prediksi memiliki nilai rata-rata konsentrasi $\mathrm{PM}_{2.5}$ di Kota Bandung cukup tinggi dengan status unhealthy for sensitive group. Nilai rata-rata untuk orde satu sebesar $42,58 \mu \mathrm{g} / \mathrm{m}^{3}$ dan untuk orde dua sebesar $42,78 \mu \mathrm{g} / \mathrm{m}^{3}$. Hasil prediksi konsentrasi minimum $\mathrm{PM}_{2.5}$ untuk orde satu terdapat di Jl. Kaum sebesar $34,56 \mu g / \mathrm{m}^{3}$ dan orde dua terdapat di Jl. Cigagak sebesar $33,62 \mu \mathrm{g} / \mathrm{m}^{3}$. Hasil prediksi konsentrasi maksimum $\mathrm{PM}_{2.5}$ untuk orde satu terdapat di Jl. Tonggoh sebesar $54,35 \mu \mathrm{g} / \mathrm{m}^{3}$ dan orde dua terdapat Jl. Geger Kalong sebesar $59,79 \mu \mathrm{g} / \mathrm{m}^{3}$. Hasil prediksi dan variansi kriging konsentrasi $\mathrm{PM}_{2.5}$ pada lokasi yang tidak tersempel dengan metode Universal Kriging orde satu dan orde dua memiliki nilai yang bervariasi. Hal ini disebabkan oleh data hasil pengamatan yang memiliki kecenderungan trend(drift) tertentu. Persamaan trend orde satu memiliki nilai variansi eror yang minimum dibandingkan persamaan trend orde dua yaitu sebesar 167,22, sehingga metode Universal Kringing menggunakan persamaan trend orde satu lebih baik digunakan untuk memprediksi konsentrasi $\mathrm{PM}_{2.5}$ pada lokasi yang tidak tersampel.

\subsection{Peta Kontur}

Peta kontur dibuat untuk memvisualisasikan hasil prediksi konsentrasi $\mathrm{PM}_{2.5}$ yang berfungsi untuk mempermudah dalam melihat lokasi dengan pencemaran tinggi maupun rendah. Peta kontur yang dibangun memperlihatkan seluruh 69 lokasi prediksi serta konsentrasi $\mathbf{P M}_{2.5}$. Peta kontur yang dihasilkan dengan bantuan menggunakan software ArcGIS 10.4 [8] untuk metode Universal Kriging dengan persamaan trend orde satu dan orde dua dapat dilihat pada Gambar 7 sebagai berikut: 


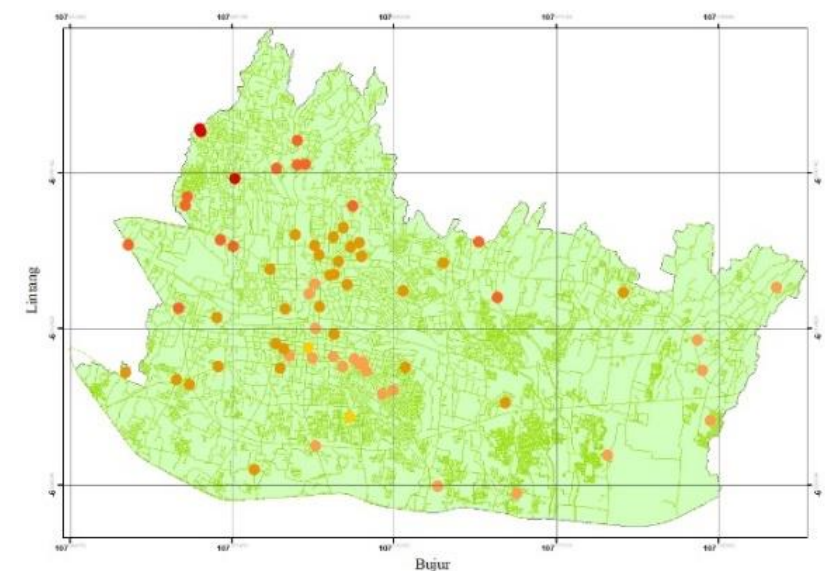

(a) Orde Satu

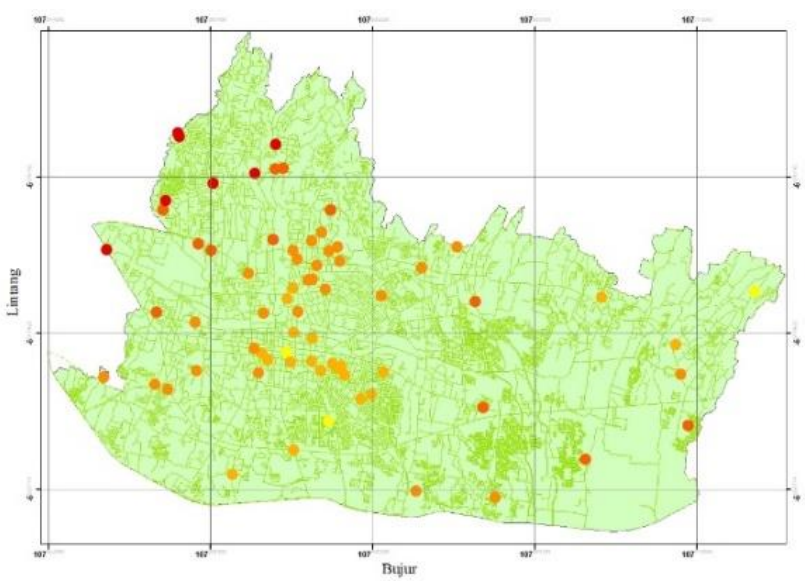

(b) Orde Dua

Gambar 7. Peta Kontur Konsentrasi PM2.5 di Kota Bandung

Warna dalam peta pada Gambar 7 menunjukan tinggi rendahnya konsentrasi $\mathrm{PM}_{2.5}$ di lokasi tersebut. Warna yang lebih gelap atau merah menunjukkan bahwa di lokasi tersebut memiliki konsentrasi $\mathrm{PM}_{2.5}$ yang tinggi, sedangkan warna yang lebih cerah atau kuning menunjukkan bahwa di lokasi tersebut memiliki konsentrasi $\mathrm{PM}_{2.5}$ yang lebih rendah. Pada peta kontur dapat diketahui warna yang lebih gelap atau merah untuk orde satu dan orde dua berada di sebelah barat laut Kota Bandung. Hal ini menunjukkan bahwa lokasi di sebelah barat laut Kota Bandung memiliki konsentrasi $\mathrm{PM}_{2.5}$ yang tinggi, sehingga dibutuhkan penanganan yang lebih khusus dari pemerintah. Berdasarkan hasil prediksi di lokasi tidak tersempel terdapat 3 lokasi dengan status unhealty untuk orde satu, yaitu Jl. Geger Kalong, Jl. Tonggoh, dan Jl. Ir. Sutami dan 7 lokasi dengan status unhealthy untuk orde dua, yaitu Jl. Negla Sari, Jl. Raya Cimindi, Jl. Geger Kalong, Jl. Tonggoh, Jl. Ir. Sutami, Jl. Sari Wangi, dan Jl. Kapt.Tendean, sedangkan lokasi lainnya dalam status moderate hingga unhealthy for sensitive groups. Lokasi-lokasi tersebut ditunjukkan dengan titik-titik berwarna merah (unhealthy) dan warna kuning (moderate). Hasil peta kontur ini dapat digunakan sebagai petunjuk wilayah yang memiliki konsentrasi $\mathrm{PM}_{2.5}$ yang tinggi atau rendah, sehingga diharapkan menjadi masukan bagi instansi terkait dalam menangani pencemaran udara di Kota Bandung.

\section{KESIMPULAN}

1. Metode Universal Kriging dengan semivariogram eksponensial dapat diterapkan pada data konsentrasi $\mathrm{PM}_{2.5}$ di Kota Bandung dikarenakan data konsentrasi $\mathrm{PM}_{2.5}$ yang diamati tidak stasioner. Berdasarkan hasil perbandingan persamaan trend orde satu dan orde dua pada 10 lokasi tersampel dengan asumsi lokasi tersebut tidak tersampel, diperoleh persamaan trend orde satu lebih baik digunakan untuk memprediksi konsentrasi $\mathrm{PM}_{2.5}$ dikarenakan memiliki nilai SSE yang minimum dibandingkan persamaan trend orde dua. Berdasarkan hasil prediksi konsentrasi $\mathrm{PM}_{2.5}$ pada lokasi yang tidak tersampel, diperoleh persamaan trend orde satu lebih akurat digunakan untuk memprediksi konsentrasi $\mathbf{P M}_{2.5}$ dikarenakan memiliki nilai variansi eror Universal Kriging yang minimum dibandingkan persamaan trend orde dua.

2. Pada peta kontur dapat dilihat warna yang lebih gelap atau merah untuk orde satu dan orde dua berada di sebelah barat laut Kota Bandung. Berdasarkan hasil prediksi di lokasi tidak tersempel terdapat 3 lokasi dalam status unhealty untuk orde satu, dan 7 lokasi dalam status unhealthy untuk orde dua, sedangkan lokasi lainnya dalam status moderate hingga unhealthy for sensitive groups.

3. Hasil penelitian dapat digunakan sebagai masukan bagi pengambil kebijakan dalam menangani masalah pencemaran di kota Bandung. Diharapkan dilakukan survey dan pengolahan data secara rutin sehingga diperoleh dampak usaha penanganan pencemaran lingkungan.

\section{UCAPAN TERIMA KASIH}

Penulis mengucapkan terima kasih kepada Rektor Universitas Padjadjaran yang telah memberikan dukungan dalam diseminasi hasil penelitian dosen dan mahasiswa melalui Hibah Internal Academic Leadership Grant (ALG) dengan nomor kontrak: 1427/UN6.3.1/LT/2020 dan reviewer yang telah memberikan masukan untuk perbaikan paper ini. 


\section{DAFTAR PUSTAKA}

[1] M. Armstrong, Basic Linear Geostatistics, Jerman: Springer, 1998.

[2] Badan Pusat Statistik, Kota Bandung dalam Angka. Bandung: Badan Pusat Statistik Provinsi Jawa Barat, 2018

[3] N. Cressie, Statistics for Spatial Data, Revised Edition, New York: John Wiley and Sons. Inc, 1993.

[4] A. N. Falah, B. Subartini, dan B. N. Ruchjana, "Application of Universal Kriging for Prediction Pollutant using GStat R". Journal of Physics: Conf. Series 893 012022, 2017.

[5] M. Greenstone, dan F. Qing, "Kualitas Udara Indonesia yang Memburuk dan Dampaknya terhadap Harapan Hidup", Indonesia report: Energy Policy Institute at the University of Chicago, 2019.

[6] S. Y. Kim, S. J. Yi, Y. S. Eum, H. J. Choi, H. Shin, H. G. Ryou, dan H. Kim, "Ordinary Kriging Approach to Predicting Long-term Particulate Matter Concentrations in Seven Major Korean Cities". Environmental Health and Toxicology, Vol. 29, eISSN: 2233-6567, 2014.

[7] R. A. Olea, Geostatistics for Engineers and Earth Scientists, United States of America: Kluwer Academic Publishers, 1999.

[8] A. Prasetyo, Modul Dasar ArcGIS 10 Aplikasi Pengelolaan Sumberdaya Alam, Bogor: Institut Pertanian Bogor, 2011.

[9] G. Rozalia, Y. Hasbi, dan D. Ispriyanti, "Penerapan Metode Ordinary Kriging pada Pendugaan Kadar NO2 di Udara (Studi Kasus: Pencemaran Udara di Kota Semarang)", Jurnal Gaussian, Vol.5, No. 1, ISSN: 2339-2541, 2016.

[10] M. Santoso, D. D. Lestiani, R. Mukhtar, E. Hamonangan, H. Syafrul, A.Markwitz, dan P. K. Hopke "Preliminary Study of the Sources of Ambient Air Pollution in Serpong Indonesia", Atmospheric Pollution Reseaarch 2 190196, 2011.

[11] J. H. Seinfeld, dan S. N. Pandis, Atmospheric Chemistry and Physics, From Air Pollution to Climate Change. Wiley-Interscience, 1997.

[12] Suhartono, Analisis Data Statistik dengan R, Surabaya: Lab. Statistik Komputasi, ITS, 2008.

[13] H. Xu, M. J. Bechle, M. Wang, A. A. Szpiro, S. Vedal, Y. Bai, dan J. D. Marshall, " $\mathrm{PM}_{2.5}$ and $\mathrm{NO}_{2}$ Exposure Models for China Based on Land use Regression, Satellite Measurement, and Universal Kriging", Science of the Total Environment 655, 2019.

[14] World Health Organization, Monitoring Health for The SDGs, Sustainable Development Goals. Geneva: World Health Organization, 2018. 
